\title{
EFEKTIVITAS EKSTRAK DAUN BELUNTAS (PLUCHEA INDICA) TERHADAP MORTALITAS ULAT KUBIS PLUTELLA XYLOSTELLA
}

\author{
Yudo Sakti ${ }^{1}$, Retno Wijayanti ${ }^{2}$, Sholahuddin $^{2)}$ \\ 1) Mahasiswa Program Studi Agroteknologi Fakultas Pertanian UNS Surakarta \\ 2) Staf Pengajar Program Studi Agroteknologi Fakultas Pertanian UNS Surakarta \\ Author Contact: Retnowijayanti@staff.uns.ac.id
}

\begin{abstract}
One type of vegetable products in Indonesia is cabbage. However, in the application of cultivating cabbage vegetables had experienced some problems, especially the crop caterpillar of Plutella xylostella. Pest control at the level of farmers in some areas, generally they still use chemical pesticides. As a solution for excessive use of chemical pesticides, the use of botanical insecticides is interesting to develop. One of the plant materials that is easily found in the surrounding environment is "beluntas" leaf (Pluchea indica L) containing alkaloids, flavonoids, saponnins, and tannins. The purpose of this study was to determine the effect of leaves extract of $(P$. indica) on caterpillar mortality of $P$. xylostella and the phytotoxicity effect on pakcoy. The results of the research showed that the extract wasn't sufficiently able to affect the larvae mortality of $P$. xylostella, The treatment concentration of $30 \%$ however was able to suppress the emergence of the imago. The extract did not show any phytotoxicity symptom the pakcoy .
\end{abstract}

Keywords: Botanical Pesticides, Life Survival, Toxic

AGROTECHNOLOGY RESEARCH JOURNAL

Sakti Y, Sholahuddin, Wijayanti R. 2018. Efektivitas ekstrak daun beluntas (Pluchea indica) terhadap mortalitas ulat kubis Plutella xylostella. Agrotech Res J 2(2): 74-79.

Sakti Y, Sholahuddin, Wijayanti R. 2018. Effectiveness of leaf extract of (Pluchea indica) on cabbage caterpillar mortality of Plutella xylostella. Agrotech Res J 2(2): 74-79.

\section{PENDAHULUAN}

Indonesia memiliki cakupan komoditas pertanian yang luas. Salah satu jenis produk pertanian di Indonesia adalah jenis sayuran. Terdapat banyak jenis sayuran yang ada di Indonesia. Salah satu sayuran yang memiliki potensi untuk dikembangkan adalah kubis (Brassica oleracea $\mathrm{L}$ ) dengan rata rata produksi 1.443.232 Ton pada tahun 2015 yang mengalami peningkatan menjadi 1.513.315 Ton pada tahun 2016 (BPS dan Direktorat Jendral Hortikultura 2017).Namun, dalam penerapan budidayanya, sayuran kubis banyak mengalami kendala terutama hama ulat. Salah satu hama yang menyerang kubis adalah ulat Plutella xylostella L.. Beberapa peneliti telah melaporkan bahwa Plutella xylostella sebagai hama utama tanaman kubiskubisan (Talekar dan Shelton 1993; Sastrosiswojo et al. 2005; Winarto dan Sebayang 2015). Nayar dan Thorsteinson (1963) dan Muller et al. (2010) menerangkan bahwa pada tanaman kubis terdapat mustard oil glucosinolate yang berperan sebagai perangsang makan dan perangsang oviposisi Plutella xylostella, sehingga tanaman ini bisa menjadi inang dari hama $P$. xylostella (Reed et al. 1989).

Pengendalian hama kubis di tingkat petani pada beberapa daerah umumnya masih menggunakan pestisida kimia (Prabaningrum et al. 2013). Dampak negatif yang timbul sebagai akibat penggunaan pestisida yang intensif antara lain adalah hama ulat daun kubis ( $P$. xylostella) menjadi resisten terhadap beberapa jenis insektisida kimia (Udiarto dan Setiawati 2007 dan Furlong et al 2013). Upaya yang dapat dikembangkan adalah penggunaan insektisida nabati dengan bahan tumbuhan. Menurut Yusuf (2012), insektisida nabati mendapat perhatian menggantikan insektisida kimia sintetik karena relatif aman bagi tanaman dan lingkungan, serta efektivitas insektisida botani juga tidak kalah dibandingkan insektisida kimia. Salah satu tumbuhan yang potensial dikembangkan menjadi pestisida nabati adalah Beluntas (Pluchea indica). Muta'ali dan Purwani (2015) dalam pengujianya menemukan bahwa ekstrak daun beluntas memiliki potensi sebagai insektisida terhadap Spodoptera litura. Hal tersebut mengindikasikan bahwa ekstrak daun beluntas bisa juga bersifat toksik terhadap $P$. xylostella karena $P$. xylostella dan S. Litura masuk dalam ordo yang sama yaitu Lepidotera.

\section{METODE PENELITIAN}

Penelitian dilaksanakan bulan Februari sampai Juli 2018 di Laboratorium Pusat Fakultas MIPA dan Laboratorium Rumah Kaca Fakultas Pertanian, Universitas Sebelas Maret Surakarta. Bahan dan alat meliputi; benih pakcoy, larva ulat daun kubis (Plutella xylostella), daun beluntas, larutan madu, daun pakcoy, aquadest, kurungan kasa ukuran $30 \mathrm{~cm} \times 30 \mathrm{~cm} \times 60$ $\mathrm{cm}$, toples plastik.

Metode yang digunakan dalam ektstraksi adalah metode soxhletasi dengan pelarut etanol $75 \%$. Langkah pertama dalam proses ekstraksi yaitu mencampurkan daun dan etanol menggunakan blender dengan perbandingan 1:5. Selanjutnya di homogenkan dengan shaker selama 24 jam. Kemudian menyaring larutan tersebut hingga bersih dan sudah tidak ada lagi residu. Pekerjaan ini dilakukan hingga filtrat yang disaring berwarna bening. Larutan hasil filtrat kemudian diuapkan dengan alat kolom destilasi dengan suhu $85^{\circ} \mathrm{C}$ untuk memisahkan larutan dari pelarutnya 
sehingga dihasilkan ekstrak beluntas dengan kandungan kimia tertentu seperti metabolit sekunder, selanjutnya tahap akhir dari pembuatan ekstrak yaitu pengovenan dengan suhu $80^{\circ}$ selama tiga jam (Setyaningrum 2018).

Pengujian uji toksisitas dilaksanakan di laboratorium pusat Fakultas MIPA UNS. Rancangan penelitian yang dilakukan adalah dengan menggunakan Rancangan Acak Lengkap dengan 5 perlakuan dan 4 kali pengulangan. Setiap perlakuan akan diberi 10 larva instar 2-3.. Perlakuan yang diujikan berdasarkan hasil penelitian Muta'ali dan Purwani (2015) yang menunjukkan $\mathrm{LC}_{50} 28 \%$ untuk Spodoptera litura pada ekstrak beluntas adalah; $\mathrm{AO}$ : Kontrol Air Aquadest, A1: Konsentrasi $5 \%$, A2: Konsentrasi $10 \%$, A3: Konsentrasi $20 \%$, A4: Konsentrasi $30 \%$. Pengamatan peubah yang diamati meliputi mortalitas larva, keberhasilan hidup, dan kemampuan makan.

Uji fitotoksisitas dilaksanakan di Laboratorium rumah kaca fakultas pertanian UNS. Uji ini dilakukan dengan penyemprotan ekstrak berbagai konsentrasi ke daun pakcoy. Pengamatan dilakukan dengan melihat gejala seperti bagian daun yang terbakar, bercak kuning dan nekrosis (Syahputra et al. 2007; Anshori 2017). Data yang didapat diolah terlebih dahulu dengan menggunakan Microsoft excel. Selanjutnya, Analisis statistik dilakukan dengan ANOVA (One way-Anova) dan uji DMRT menggunakan SPSS dengan tingkat kepercayaan 95\% dilakukan untuk membandingkan antar perlakuan (Anshori 2017).

\section{HASIL DAN PEMBAHASAN}

\section{Uji mortalitas larva}

Mortalitas akibat racun yang dihasilkan oleh suatu bahan merupakan salah satu syarat yang harus dilakukan dalam mengembangkan jenis pestisida nabati. Mortalitas yang semakin tinggi akan mengindikasikan seberapa efektif suatu bahan tanaman dapat membunuh larva. Tidak semua jenis pestisida nabati tingkat kematian sejalan dengan tingkat konsentrasi. Hasil penelitian menunjukkan pemberian ekstrak beluntas tidak cukup mampu mempengaruhi mortalitas larva (Gambar 1).

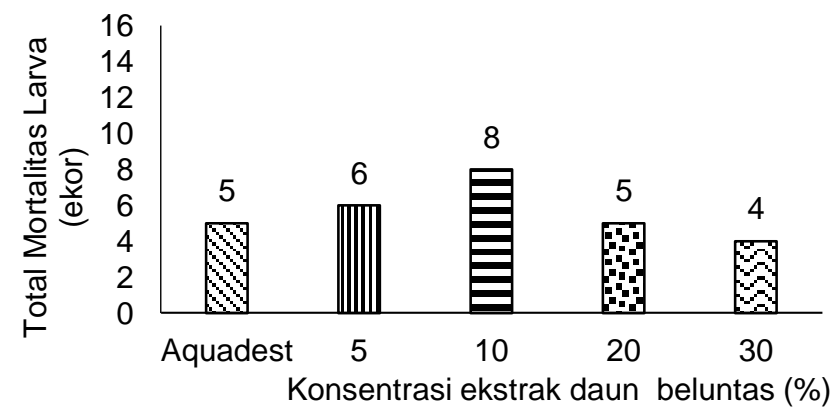

Gambar 1 Histogram total mortalitas larva P.xylostella hingga hari ke-7

Penelitian menunjukkan pada konsentrasi 10\% lebih mampu mempengaruhi mortalitas larva sebesar $20 \%$ dari total larva 40. Sa'diyah et al. (2013) menyatakan bahwa mortalitas larva akibat pemberian ekstrak tanaman dapat terjadi akibat adanya senyawa aktif seperti tanin, saponin, alkaloid, dan flavonoid didalam tanaman tersebut. Hasil yang berfluktuatif pada mortalitas larva yang terjadi juga diduga akibat suhu yang sangat tinggi dan kelembaban yang rendah di ruang pengujian. Liu et al. (2002) dan Golizadeh et al. (2009) dalam penelitianya menunjukkan adanya pengaruh suhu dalam mempengaruhi perkembangan larva $P$. xylostella. Ngowi et al. (2017) menambahkan bahwa suhu yang sangat baik dalam keberhasilan hidup $P$. xylostella fase larva dan pupa sekitar $20^{\circ} \mathrm{C}$. Saat penelitian dilakukan, suhu rata-rata ruangan adalah 29,37 ${ }^{\circ} \mathrm{C}$. Pada hasil penelitian Makal dan Turang (2011) menunjukkan adanya kematian bahkan pada kontrol, hal ini disebabkan oleh tekanan faktor lingkungan di dalam laboratorium atau akibat dari perlakuan pada tahap persiapan atau saat penelitian berlangsung. Sunjaya (1970) cit. Makal dan Turang (2011) menambahkan bahwa serangga akan terhambat pertumbuhan dan perkembanganya bahkan bisa mati apabila faktor tempat lingkungan tempat hidupnya tidak mendukung.

Tabel 1 Korelasi determinasi ekstrak daun beluntas terhadap mortalitas larva $P$. xylostella

\begin{tabular}{cccc}
\hline Nilai $R$ & $\mathrm{R}^{2}$ & $\begin{array}{c}\mathrm{R}^{2} \text { yang } \\
\text { disesuaikan }\end{array}$ & $\begin{array}{c}\text { Perkiraan } \\
\text { std. error } \\
\mathrm{R}^{2}\end{array}$ \\
\hline $0,113^{\mathrm{a}}$ & 0,013 & $-0,042$ & 1,459 \\
\hline
\end{tabular}

Tabel 2 Korelasi determinasi suhu dan kelembaban terhadap mortalitas larva $P$. xylostella

\begin{tabular}{cccc}
\hline Nilai $R$ & $\mathrm{R}^{2}$ & $\begin{array}{c}\mathrm{R}^{2} \text { yang } \\
\text { disesuaikan }\end{array}$ & $\begin{array}{c}\text { Perkiraan } \\
\text { std. error } \\
\mathrm{R}^{2}\end{array}$ \\
\hline $0,582^{\mathrm{a}}$ & 0,338 & 0,260 & 1,229 \\
\hline
\end{tabular}

Berdasarkan hasil analisis korelasi determinasi (Tabel 1 dan 2) menunjukkan adanya dominansi lebih dari suhu dan kelembaban yang menyebabkan kematian terhadap larva dengan besaran 33,8\%. Pada perlakuan sendiri hanya menyebabkan kematian dengan besaran 1,3\%. Sehingga dapat dikatakan bahwa kematian pada larva yang terjadi saat penelitian lebih diakibatkan oleh suhu yang tinggi dan kelembaban yang rendah di lingkungan pengujian. Hal ini menunjukkan ekstrak beluntas metode soxhletasi belum mampu mempengaruhi mortalitas larva $P$. xylostella. Muta'ali dan Purwani (2015) dalam penelitiannya menunjukkan keefektifan ektsrak daun beluntas dengan metode maserasi dalam mempengaruhi mortalitas larva S.litura ( $\mathrm{LC}_{50} 28 \%$ ). Ketidak-efektifan ekstrak beluntas dalam mempengaruhi mortalitas juga diduga disebabkan oleh jenis cara kerja pestisida dari beluntas itu sendiri yaitu sebagai racun perut. Cara kerja pestisida racun perut menurut Hudayya dan Jayanti (2012) adalah merusak sistem pencernaan jika tertelan oleh serangga sehingga akan memiliki dampak secara berangsur-angsur terhadap perkembangan berikutnya dari $P$. xylostella. 


\section{Keberhasilan hidup}

Besaran daya mortalitas yang diakibatkan oleh pemberian larutan akan berpengaruh terhadap keberhasilan hidup larva uji. Masih rendahnya mortalitas pada fase larva mengindikasikan larva mampu berkembang hingga ke fase pupa. Pemberian ekstrak daun beluntas $10 \%$ mampu menurunkan persentase keberhasilan pembentukan pupa sebesar $8,5 \%$ dari kontrol. Namun, terjadi peningkatan keberhasilan pembentukan pupa pada ekstrak $30 \%$ (Gambar 2).

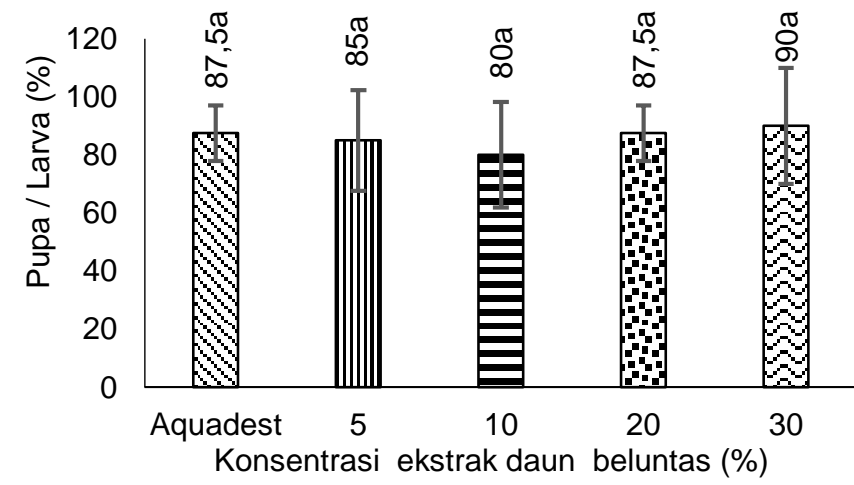

Gambar 2 Histogram keberhasilan hidup larva menjadi pupa $P$. xylostella

Keberhasilan hidup ulat menjadi pupa yang masih cukup tinggi setiap perlakuan menandakan adanya perkembangan pupa akan menjadi imago. Hasil penelitian menunjukkan pemberian ekstrak daun beluntas konsentrasi $30 \%$ mampu menurunkan kemunculan imago. Namun, pada konsentrasi 5\%, $10 \%$, dan $20 \%$ tidak cukup mampu menurunkan keberhasilan kemunculan imago (Gambar 3).

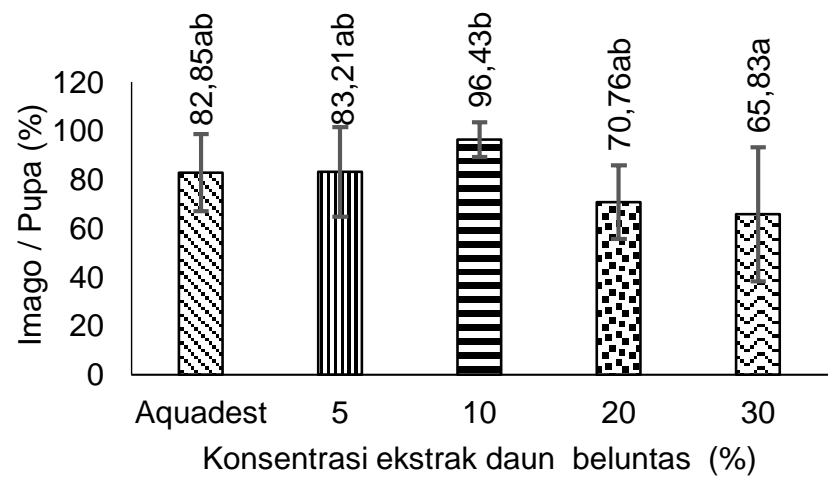

Gambar 3 Histogram keberhasilan hidup pupa menjadi imago P. xylostella

Keberhasilan hidup yang rendah dengan aplikasi ekstrak 30\% disebabkan adanya senyawa yang mampu menghambat perkembangan pada fase pupa menuju imago. Hal ini didukung dengan pernyataan Begna dan Damtew (2015) dalam penelitiannya yang menyatakan bahwa pestisida nabati dapat memberikan efek pada perkembangan tahap pupa. Fitokimia dalam senyawa botani memiliki kapasitas cukup untuk mengurangi kemunculan imago hingga ke tingkat yang rendah.
Berdasarkan Gambar 2 dan 3 dapat dibuat histogram larva-imago seperti pada Gambar 4. Keberhasilan hidup larva menjadi imago pada setiap perlakuan konsentrasi menunjukkan pemberian ekstrak daun beluntas dengan konsentrasi sebesar $20 \%$ dan $30 \%$ cukup mampu menekan keberhasilan hidup larva menjadi imago (Gambar 4).

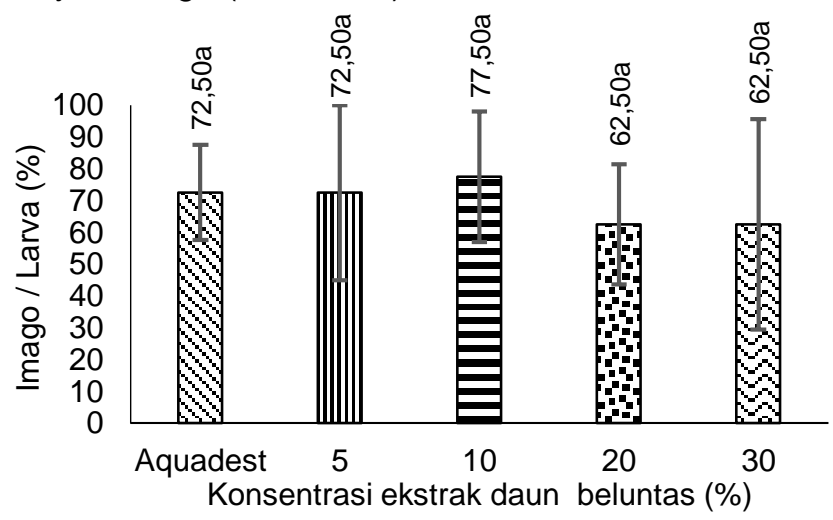

Gambar 4 Histogram keberhasilan hidup larva menjadi imago $P$. xylostella

Keberhasilan kemunculan imago yang masih cukup tinggi antar perlakuan bisa disebabkan oleh beberapa faktor salah satunya adalah keberadaan kandungan bahan aktif dari daun beluntas yang digunakan. Kaufman et al. (1999) cit Dadang dan Prijono (2008) menyatakan bahwa kandungan bahan aktif dalam tumbuhan sering beragam, bergantung pada keragaman genetika tumbuhan, keadaan geografi daerah asal tumbuhan tersebut, fase pertumbuhan, dan musim saat pemanenan bagian yang mengandung bahan insektisida. Yuliani et al. (2015) dalam penelitiannya menemukan adanya perbedaan kandungan beberapa senyawa fenol dalam beluntas yang diambil dari berbagai ketinggian. Satasook et al. (1994); Prijono et al. (2001) menambahkan bahwa cara penanganan bagian tumbuhan tersebut dan cara ekstraksi dapat juga mempengaruhi keefektifan insektisida nabati yang diperoleh. Mandal et al. (2008); Li Ya et al. (2017); dan Wazziroh et al. (2018) menyatakan bahwa Microwave Assisted Extraction (MAE) merupakan cara ekstraksi terbaru yang menunjukkan ketelitian dan hasil yang lebih baik (tinggi) dengan waktu yang cepat dibandingkan dengan cara ekstraksi konvensional (soxhletasi dan maserasi). Widyawati et al (2014) dalam penelitiannya menunjukkan adanya perbedaan hasil kandungan yang berbeda dari setiap jenis pelarut yang digunakan dalam ekstraksi. Beberapa kandungan senyawa yang berada dalam tanaman akan banyak keluar ketika menggunakan ekstrak dengan pelarut methanol. Selain methanol, pelarut yang memiliki keefektifan dalam mengeluarkan senyawa dalam tanaman adalah Etanol jenis P.A (Pro-Analysis) yang memiliki kualitas sangat baik karena tingkat kemurniannya. Menurut Christian (1980) senyawa kimia jenis Pro-Analisis adalah senyawa kimia yang harus digunakan untuk analisis yang memerlukan ketelitian tinggi. Namun penggunaan senyawa kimia jenis ini dari segi kepraktisan petani tradisional tidak praktis karena memiliki harga yang sangat mahal. Selain itu, ketidak-efektifan ekstrak juga 
diduga karena dalam larutan tersebut telah terjadi penyusutan reaksi kimia dimana dari berbagai penelitian diketahui bahwa beberapa golongan flavonoid ada yang sensitif terhadap panas. Ketika proses pemanasan dan selama waktu penyimpanan akan menyebabkan flavonoid mengalami degradasi kimia (Mrmosanin et al. 2015). Talogo (2014) menambahkan bahwa suhu sangat mempengaruhi degradasi kimiawi, fisika dan mikrobiologi. Srivastava et al. (2007) dalam penelitiannya pada ekstrak bluberi menunjukkan bahwa penyimpanan ekstrak berkepanjangan pada suhu kamar secara signifikan mengurangi senyawa fenolik dan sifat biologis ekstrak.

\section{Kemampuan makan}

Tingginya keberhasilan hidup ulat menjadi pupa pada setiap perlakuan menunjukan kemampuan makan yang masih tinggi pada fase larva. Kemampuan makan yang masih tinggi akan berpengaruh pada luas persentase kerusakan daun uji. Hasil penelitian menunjukkan pemberian ekstrak daun beluntas tidak cukup efektif dalam menurunkan kerusakan daun akibat larva (Gambar 5).

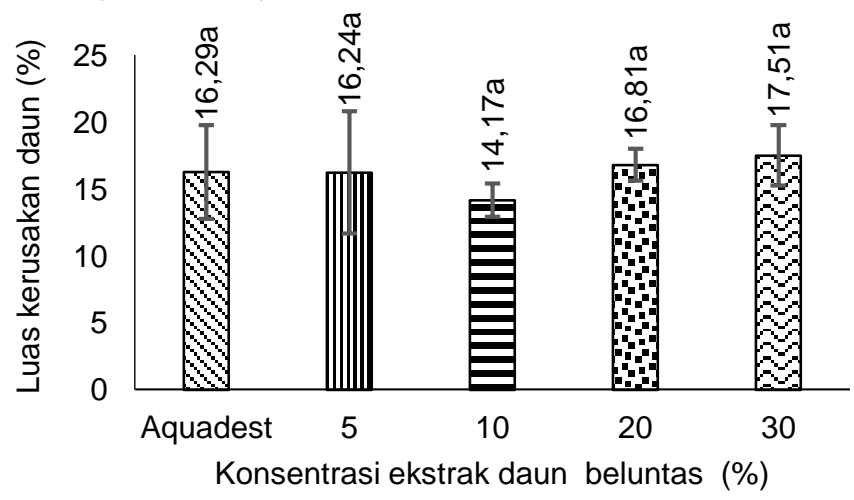

Gambar 5 Persentase luas kerusakan daun oleh larva P. xylostella

Kecil dan besarnya persentase luas kerusakan pada perlakuan dipengaruhi oleh jumlah larva yang masih hidup setiap harinya (Tabel 3 ). Larva yang masih banyak menunjukkan perlakuan konsentrasi yang diberikan tidak berpengaruh dalam menghambat larva dalam proses memakan. Tidak adanya hambatan makan (Antifeedant) terhadap $P$. xylostella diduga karena adanya senyawa yang membantu menambah nafsu makan $P$. xylostella. Pada kehidupan sehari hari biasanya beluntas sendiri sering dimanfaatkan untuk menambah nafsu makan pada manusia (Dalimartha 1999; Permadi 2008). Luas kerusakan yang berbeda beda pada Gambar 5 juga dipengaruhi oleh jumlah larva yang masih hidup setiap harinya (Tabel 3).

Tabel 3 Jumlah larva hidup $P$. xylostella setelah diaplikasi dengan ekstrak daun beluntas

\begin{tabular}{lc}
\hline Konsentrasi (\%) & Rata-rata jumlah larva \\
\hline Aquadest & 8,75 \\
5 & 8,50 \\
10 & 8,00 \\
20 & 8,75 \\
30 & 9,00 \\
\hline
\end{tabular}

Serangga uji yang tidak tahan memakan senyawa aktif akan mengalami kematian dan serangga yang toleran akan tetap bertahan dengan kondisi tertentu. Serangga yang tidak tahan terhadap senyawa aktif tersebut, sebelum akhirnya mati serangga dapat tetap bertahan dengan memaksimumkan pemanfaatan sumber energi di dalam tubuhnya dengan memakan daun uji dalam jumlah yang tidak banyak. Larva tersebut tentunya akan mengalami hambatan pertumbuhan dan perkembangan sebagai konsekuensi dari keadaan tersebut. Serangga yang toleran, melalui sistem metabolisme senyawa asing dalam tubuh serangga, serangga akan menetralkan atau mendetoksifikasi senyawa aktif menjadi tidak aktif, sehingga serangga dapat beradaptasi dengan senyawa tersebut (Syahputra et al. 2006). Larva yang mampu beradaptasi dengan senyawa dan besaran konsentrasi akan mampu berubah ke tahap selanjutnya menjadi pupa. Namun, Pupa yang berasal dari larva terkontaminasi, pada tahap selanjutnya akan mengalami hambatan dalam perkembangannya menjadi imago (Gambar 3).

\section{Uji fitotoksisitas}

Pemberian pestisida baik pestisida nabati maupun kimia selain akan mengenai sasaran utama yakni hama , juga akan mengenai bagian tanaman yang teraplikasi. Penggunaan pestisida perlu memperhatikan bahan, formulasi, dan dosis yang akan digunakan. Penggunaan yang tidak sesuai akan menyebabkan gejala fitotoksisitas. Gejala fitotoksisitas yang akan timbul antara lain: tepi, permukan dan bagian seluruh daun bisa terbakar, bercak kuning pada daun serta nekrosis (Getter 2015). Hasil yang didapat menunjukan bahwa tidak adanya gejala fitotoksisitas terhadap tanaman uji pada $4 \mathrm{HSP}$ dengan 4 perlakuan konsentrasi (Tabel 4)

Tabel 4 Pengamatan tanaman uji pada 4 HSP

\begin{tabular}{lccc}
\hline \multirow{2}{*}{$(\%)$} & \multicolumn{3}{c}{ Gejala fitotoksisitas } \\
\cline { 2 - 4 } & $\begin{array}{c}\text { Bagian daun } \\
\text { terbakar }\end{array}$ & $\begin{array}{c}\text { Bercak } \\
\text { kuning }\end{array}$ & Nekrosis \\
\hline Aquadest & - & - & - \\
5 & - & - & - \\
10 & - & - & - \\
20 & - & - & - \\
30 & - & - & - \\
\hline
\end{tabular}

Tidak adanya gejala fitotoksisitas menunjukkan bahwa pada kandungan ekstrak daun beluntas dengan konsentrasi 5\%, 10\%, 20\%, 30\% tidak bersifat meracuni tanaman. Anshori (2017) dalam penelitianya menunjukkan adanya gejala fitotoksisitas yang diakibatkan oleh adanya senyawa monoterpena. Beberapa Monoterpena dalam tanaman menurut Brown (1987); Reid et al. (2017) dalam penelitiannya menunjukkan bahwa senyawa monoterpena bersifat toksik. Ludwiczuk (2017) menjelaskan bahwa senyawa monoterpenoid adalah senyawa berupa antara lain; myrcene, limonene, pinene, linalool dan citral. Senyawa yang terkandung dalam beluntas sendiri oleh Rukmiasih (2011); Ahemd dan Kamel (2013); dan Widyawati et al. (2016) adalah alkaloid,saponnin,tannin 
dan flavonoid, terpene dan senyawa fenolik lainnya. Sehingga diduga dalam larutan ekstrak beluntas yang diaplikasikan tersebut tidak terdapat senyawa yang bersifat toksik terhadap tanaman pakcoy uji.

\section{KESIMPULAN DAN SARAN}

\section{Kesimpulan}

Kesimpulan yang didapat dari hasil penelitian uji efektivitas ekstrak beluntas terhadap mortalias ulat daun kubis (Plutella xylostella) adalah:

1. Ekstrak daun beluntas dengan konsentrasi maksimal $30 \%$ belum mampu mempengaruhi mortalitas $P$. xylostella.

2. Ekstrak daun beluntas konsentrasi $30 \%$ mampu menekan kemunculan imago $P$. xylostella sebesar $35 \%$.

3. Ekstrak daun beluntas tidak bersifat fitotoksik terhadap tanaman.

\section{Saran}

Saran yang dapat diberikan berdasarkan penelitian ini adalah beluntas merupakan tanaman potensial yang bisa digunakan sebagai alternatif penggunaan pestisida kimia yang berlebihan. Diharapkan di penelitian lanjutan lebih dikembangkan dengan cara ekstraksi yang berbeda dan dengan konsentrasi yang lebih tinggi.

\section{DAFTAR PUSTAKA}

Ahemd dan Kamel. 2013. Phenolic constituents and biological activity of the genus pluchea. Der Pharma Chem. 5(5):109-114. http://derpharmachemica.com /archive.html.

Anshori NMA. 2017. Potensi minyak atsiri kulit buah jeruk nipis untuk pengendalian Crocidolomia pavonana.[Skripsi]. Surakarta: UNS.

[BPS] Badan Pusat Statistik dan Direktorat Jenderal Hortikultura. 2017. Produksi, luas panen, dan produktivitas sayuran di indonesia. Dalam Kementerian Pertanian. 2017. Statistik Pertanian. http://epublikasi.setjen.pertanian.go.id/download/file/ 390-statistik-pertanian-2017. Diakses pada tanggal 7 Juli 2018.

Begna F dan Damtew T. 2015. Evaluation of four botanical insecticides against Diamondback Moth, Plutella xylostella L. (Lepidoptera: Plutellidae) on head cabbage in the central rift valley of Ethiopia. Sky J Agri Res. 4(5): 097 - 105.

Brown JT, Hegarty PK, Charlwood BV. 1987. The toxicity of monoterpenes to plant cell cultures. Plant Sci. 48:195-201.

Christian GD. 1980. Analytical chemistry - 3rd Edition. New York: Wiley.

Dadang dan Prijono D. 2008. Insektisida nabati: prinsip, pemanfaatan, dan pengembangan. Bogor(ID): Departemen Proteksi Tanaman, Institut Pertanian Bogor.

Dalimartha S. 1999. Atlas tumbuhan obat indonesia jilid 1. Jakarta: Trubus Agriwidya.

Furlong MJ, Wright DJ, Dosdall LM. 2013. Diamondback moth ecology and management: problems, progress and prospects. Annu Rev Entomol. 58:517-41. DOI: 10.1146/annurev-ento120811-153605.

Getter K. 2015. Plant phytotoxicity in the greenhouse. http://msue.anr.msu.edu/news/plant_phytotoxicity_in _the_greenhouse. Diakses pada tanggal 8 Juli 2018.

Golizadeh A, Kamali K, Fathipour Y, Abbasipour H. 2009. Effect of temperature on life table parameters of Plutella xylostella (Lepidoptera: Plutellidae) on two brassicaceous host plants. J Asia-Pasific Entomol. 12: 207-212.

Hudayya A dan Jayanti H. 2012. Pengelompokan pestisida berdasarkan cara kerjanya (mode of action). Lembang-Bandung (ID): Yayasan Bina Tani Sejahtera

Kaufman PB et al.. 1999. Natural products from plants. Boca Raton[FL]: CRC Press.

Li Ya et al.. 2017. Microwave-assisted extraction of natural antioxidants from the exotic gordonia axillaris fruit: optimization and identification of phenolic compounds. Molecules 22(1481): 1-16. DOI:10.3390/molecules22091481.

Liu SS, Chen FZ, Zalucki MP. 2002. Development and survival of the diamondback moth (Lepidoptera: Plutellidae) at constant and alternating temperatures. Environ Entomol. 31(2): 221-231. DOI: 10.1603/0046-225X-31.2.221.

Ludwiczuk A, Skalicka-Wozniak K, Georgiev MI. 2017. Chapter 11 - Terpenoids. Pharmacognosy : fundamentals, applications and strategies. 233-266. DOI: 10.1016/B978-0-12-802104-0.00011-1.

Makal HVG, Turang DAS. 2011. Pemanfaatan ekstrak kasar batang serai untuk pengendalian larva Crocidolomia binotalis Zell. Pada tanaman kubis. Eugenia 17(1): 16-20.

Mandal V, Mohan Y, Hemalatha S. 2008. Microwave assisted extraction of curcumin by sample-solvent dual heating mechanism using Taguchi L9 orthogonal design. J Pharma Biomed Anal. 46: 322327. DOI: 10.1016/j.jpba.2007.10.020.

Mrmosanin JM, Pavlocic AN, Veljkovic JN, Mitic SS, Tosic SB, Mitic MN. 2015. The effect of storage temperature and thermal processing on catechins, procyanidins and total flavonoid stability in commercially available cocoa powders. Series: Phy Chem Tech. 13(1): 39-49. DOI:10.2298/fupct 1501039m.

Muller $\mathrm{R}$ et al. 2010. Differential effects of indole and aliphatic glucosinolates on lepidopteran herbivores. J Chem Ecol. 36:905-913. DOI :10.1007/s10886010-9825-z.

Muta'ali R dan Purwani KI. 2015. Pengaruh ekstrak daun beluntas (Pluchea indica) terhadap mortalitas dan perkembangan larva Spodoptera litura F. J Sains Seni. 4(2): 2337-3520.

Nayar JK dan Thorsteinson AJ. 1963. Further investigations into the chemical basis of insect-host plant relationships in an oligophagous insect Plutella 
maculipennis Curt. (Lepidoptera: Plutellidae). Can J Zool. 41:923-929.

Ngowi BV et al.. 2017. Temperature-dependent phenology of Plutella xylostella (Lepidoptera: Plutellidae): Simulation and visualization of current and future distributions along the Eastern Afromontane. Plos One. 1-24. DOI: https://doi.org/10.1371/journal.pone.0173590.

Permadi A. 2008. Membuat kebun tanaman obat. Jakarta: Pustaka Bunda.

Prabaningrum L, Uhan TS, Nurwahidah U, Karmin, Hendra A. 2013. Resistensi Plutella xylostella terhadap insektisida yang umum digunakan oleh petani kubis di Sulawesi Selatan (Resistance of Plutella xylostella to insecticides used by farmers on cabbage in South Sulawesi). J Hort. 23(2):164173.

Prijono D et al. 2001. Insecticidal activity of extracts of Aglaia spp. (Meliaceae) against the cabbage cluster caterpillar, Crocidolomia binotalis Z. (Lepidoptera: Pyralidae). J Perl Tan Indon. 7:6573.

Reed DW, Pivnick KA, Underhill EW. 1989. Identification of chemical oviposition stimulants for the diamondback moth, Plutella xylostella, present in three species of Brassicaceae. Entomol Exp Appl. 53: 277-286.

Reid ML, Sekhon JK, LaFramboise LM. 2017. Toxicity of monoterpene structure, diversity and concentration to mountain pine beetles, dendroctonus ponderosae: beetle traits matter more. J Chem Ecol. DOI 10.1007/s10886-0170824-1.

Rukmiasih. 2011. Penurunan bau amis (off-odor) daging itik lokal dengan pemberian tepung daun beluntas (Pluchea indica L.) dalam pakan dan dampaknya terhadap performa.[Disertasi]. Bogor: IPB.

Sa'diyah NA, Purwanti KI, Wijayanti L. 2013. Pengaruh ekstrak daun bintaro (Cerbera odollam) terhadap perkembangan ulat grayak (Spodoptera litura F.). J Seni POMITS. 2:E-1 11.

Sastrosiswojo S, Uhan TS, Sutarya R. 2005. Penerapan teknologi pht pada tanaman kubis. Balai Penelitian Tanaman Sayuran. Lembang, Bandung.

Satasook C et al. 1994. Insecticidal bioactivity of crude extracts of Agluia species (Meliaceae). Biochem Syst Ecol. 22: 121-127.

Setyaningrum D. 2018. Penghambatan serai merah (Cymbopogon citratus) terhadap perkecambahan beberapa jenis benih.[Skripsi]. Surakarta: UNS

Srivastava A, Akoh CC, Yi W, Fischer J, Krewer G. 2007. Effect of storage conditions on the biological activity of phenolic compounds of blueberry extract packed in glass bottles. J Agric Food Chem. 55: 2705-2713. DOI: 10.1021/jf062914w.

Sunjaya PI. 1970. Dasar-dasar serangga bagian ilmu hama tanaman pertanian. Bogor: IPB.
Syahputra E et al. 2006. Respons fisiologi Crocidolomia pavonana terhadap fraksi aktif Calophyllum soulattri. Hayati. 13(1) : 7-12.

Syahputra, Prijono D, Dono D. 2007. Sediaan insektisida Calophyllum soulattri: aktivitas insektisida dan residu terhadap larva Crocidolomia pavonana dan keamanan pada tanaman. J HPT Trop 7(1): 21-29.

Talekar NS dan Shelton AM. 1993. Biology, ecology, and management of the diamondback moth. Annu Rev Entomol. 38:275-301

Talogo ASM. 2014. Pengaruh waktu dan temperatur penyimpanan terhadap tingkat degradasi kadar amoksilin dalam sediaan suspensi amoksilin-asam klavunalat.[Skripsi]. Jakarta: UIN Syarif Hidayatullah.

Udiarto BK dan Setiawati W. 2007. Suseptibilitas dan kuantifikasi resistensi 4 strain Plutella xylostella L. terhadap beberapa Insektisida. J Hort. 17(3): 277284.

Wazziroh E, Harijono dan Kamilia K. 2018. Microwaveassisted extraction (MAE) of bioactive saponin from mahogany seed (Swietenia mahogany Jacq). IOP Conf Series: Earth Environ Sci. 131(012006). DOI:10.1088/17551315/131/1/012006.

Widyawati PS, Budianta TDW, Kusuma FA, Wijaya EL. 2014. Difference of solvent polarity to phytochemical content and antioxidant activity of Pluchea indicia Less leaves extracts. Intern J Pharma Phyto Res. 6(4): 850-855.

Widyawati PS et al.. 2016. The physicochemical and antioxidant properties of Pluchea indica less drink in tea bag packaging. Intern. J Food Nutri Sci. 5(3): 113-120.

Winarto L dan Sebayang L. 2015. Teknologi pengendalian hama terpadu pada tanaman kubis. Balai Pengkajian Teknologi Pertanian. Sumatera Utara.

Yuliani, Soemarno, Yanuawidi B, Leksono AS. 2015. Total phenolic and flavonoid contents of Pluchea indica less leaves extracts from some altitude habitats. Intern J Chem Tech Res. 8(4): 16181625.

Yusuf R. 2012. Potensi dan kendala pemanfaatan pestisida nabati dalam pendalian hama pada budidaya sayuran organik. Balai Pengkajian Teknologi Pertanian Riau. Seminar UR-UKM ke-7. 